\title{
From Identity Politics to the Identitarian Movement
}

\author{
The Europeanisation of Cultural Stereotypes?
}

\author{
Karel Šima
}

\begin{abstract}
The motivation behind this contribution is to explain how the concept of identity got from the emancipatory context of identity politics to the conservative revolutionary context of nationalistic, xenophobic, far-right movements of the Generation Identity. On one hand the notion of identity was mobilised to challenge the dominant oppressive power relations by the marginal social groups based mainly on distinctiveness of ethnicity, race, gender etc. On the other hand, recent crises in Europe brought to the fore the far-right youth movements that posed the defence of identity as their main motto. The aim of this contribution is to analyse cultural references within the discourses and performances of the pan-European identitarian movement in order to understand their mechanisms of instrumentalising national, ethnic, as well as local and European cultural characteristics and values. This case study is of relevance as it not only shows cultural representations behind specific social movements reacting to recent European crises, but also explains the processes by which they are being 'europeanised' into pan-European cultural and political discourses.
\end{abstract}

\section{Introduction}

On 27 August 2016 fifteen activists from a German identitarian group climbed the iconic Brandenburg Gate in Berlin and put up banners reading "Secure borders - secure future" ["Sichere Grenzen - sichere Zukunft"] and "Protect Borders! Save lives!" ["Grenzen schützen! Leben retten!']. This demonstration took place near government buildings on a day when they were open to the public. In their performance, witnessed by a large audience, these activists presented a political agenda based on the image of an enemy from outside and gained 
significant coverage in regional as well as national media. ${ }^{1}$ More than one year later, on the $5^{00^{\text {th }}}$ anniversary of Luther's famous posting of the ninety-five theses in Wittenberg, these activists put on a "street theatre show" in front of a Berlin church, where one of them dressed as Martin Luther nailed a poster with five theses against the protestant church of Germany to the door. They criticised the church for selling "modern indulgences" in the form of refugee aid and for betraying its ideals and earning "billions" for destroying Europe. These performers also unfurled a banner featuring a picture of Luther with an identitarian logo on his forehead and emblazoned with one of his quotations: "Hypocrisy has ample wages, but truth goes a-begging" ("Für Heuchelei gibt's Geld genug, Wahrheit geht betteln"). This event was completely overlooked by the media, and photos and a corresponding statement were only published on the Facebook page of Berlin's identitarian group. ${ }^{2}$ These two demonstrations illustrate the paradoxes of this relatively recent 'movement' that has, on one hand, gained substantial media coverage, but on the other consists of small, locally marginal groups of activists that possess few resources. Identitarians play with national symbols and stereotypes, while at the same time reacting to overarching European agendas. They raise controversial political questions, but instead of engaging in political debate they counter the establishment by mixing cultural references. They communicate their agenda through social media, dressing up their traditionalist and mostly conservative political ideas in an attractive visual style. They combine the political instruments of leftist social movements with far-right ideology.

There is not much new about this self-declared pan-European identitarian 'movement,' ${ }^{3}$ except its clever strategy of exploiting its own paradoxes in an attempt to shift the mainstream public discourse towards the far right. Its strategy is based on the French New Rights ideology, which places culture at the centre of political struggle. Therefore, identitarians refuse to use classic political instruments, and instead, in their struggle for cultural hegemony, recycle and put to innovative use cultural references that reflect European and national hetero- and autostereotypes and thus frame national and European political debates with their ideology. Following this idea, I will first show how

1 See 'Rechte "Identitäre Bewegung" besetzt Brandenburger Tor' (2016).

2 All identitarian Facebook pages were banned during the first half of 2018. The author has archived copies of these pages.

3 Fabian Virchow persuasively argues that this activist current is neither 'identitarian' nor a 'movement'. Although I use the term 'identitarian' in this paper, I put 'movement' in quotation marks in keeping with Virchow's interpretation. When mentioning particular national identitarian organisations, I refer to them by the name they use. See Virchow (2015), p. 186. 
and why the concept of identity moved from the context of identity politics to become the key political driver in the identitarian 'movement'. Then I will shortly summarize the identitarian current that has been surging through Europe since 2012, before introducing its key ideological pillars and showing how identitarians put them into practice in their public cultural performances. In the conclusion I will consider the differences between different European identitarian groups and shortly reflect on this "movement's" perspectives.

\section{From Identity and Identity Politics to Identitarian Counterattack}

Social scientists and humanities scholars have long debated the concept of identity; in the 199os the scholarly discourse on identity became so widespread and was used in so many different contexts, often with vague conceptual justifications, that some authors saw no value in further developing identity theories and instead suggested using other more precise and analytically robust concepts. For example, Brubaker and Cooper differentiate between identity as a category of analysis and as a category of practice. ${ }^{4}$ While they oppose the analytical power of the concept, they acknowledge that identity in practice should be studied in the process of its reification. Thus, the key question is, how and in which circumstances can the concept of identity become a category of social, political, and cultural practice? Along these lines, I will explore the identitarian 'movement' as a specific mutation of identity politics.

Beginning in the nineteenth century, when identity ceased to be taken for granted, several forms of modern identity politics that revolved around concepts of nation, state, or class emerged. They replaced what Calhoun calls "the all-encompassing identity schemes" of the premodern era. ${ }^{5}$ In the 1950s and 196os in Western Europe and the USA identity politics began to focus on improving the lives of ethnic and sexual minorities. Even though the public discourse had changed and legal changes officially improved their status, they remained marginalised groups. At this time, the push for equal civil rights for these marginalised groups began to revolve around each group's specific 'way of life.' Thus, a new identity politics emerged that sought recognition of differences. As a result of this shift, identity politics was adopted by some new social movements (NSMs), as these activist groups were later labelled. ${ }^{6}$

4 See Brubaker, Cooper (2000).

5 Calhoun (1994), p. 11.

6 For a reflection of the concept of identity in NSM research, see, e. g., Scott, Benford, Snow (1994). 
In the 196os the term 'identity' had so thoroughly permeated the public discourse that Robert Coles complained that it had become "the purest of clichés". ${ }^{7}$ Hand in hand with the establishment of this term within academic discourse, identity became a category of practice. The term 'identity politics' emerged in the 1970s, when several NSMs grew into visible political forces providing radical critiques of the existing order. In the 1970s and 1980s activists promoting women's liberation, gay liberation, environmentalism, animal rights, the anti-nuclear movement, African-American civil rights, and other similar movements succeeded in achieving recognition and legitimacy for their agendas within the broader political discourse through various protest practises. The New Left's success in the 199os (in Britain, the USA and Germany, for example) thrust identity politics into the political mainstream and resulted in the gradual creation of an organisational and funding infrastructure. Simon Bornschier notes that this success story has not only its winners but also its losers. What he calls "cultural modernisation" has largely benefited "sociocultural specialists", who work in "client-interactive environments" with a high degree of cultural diversity. ${ }^{8}$ In opposition to them stand those who oppose cosmopolitan values and defend the traditionalist monocultural conception of community. In the 199os, however, leftist and liberal academics began to criticize the New Left's turn towards identity politics. Scholars such as Eric Hobsbawm and Richard Rorty warned that the Left's focus on identity would amount to a loss of its electorate and pave the way for dangerous populist politicians. ${ }^{9}$ A new wave of criticism has emerged following the financial and migration crises of recent years, when liberals have been shocked by the gains of populist right-wing political entrepreneurs. ${ }^{10}$ Identity politics is now facing an identitarian counterattack.

The Identitarian Wave in a Time of Crisis and Its Roots in Far-Right Politics

The official kick off of the European identitarian 'movement' that initiated the Generation Identity brand internationally was a local protest held on 20 October 2012 in Poitier, France. Several dozen activists occupied a mosque under construction, unfurling black-and-yellow banners that read "Generation

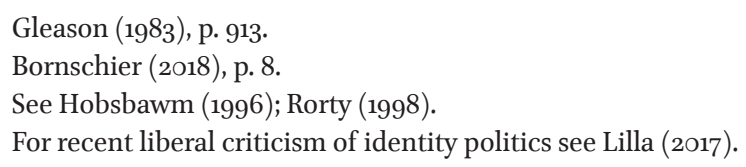


Identitaire $73^{2}$ and featured the Greek lambda symbol.1 ${ }^{11}$ These activists had a well-established background in the Bloc Identitaire party that was founded in 2003 as a successor to Unité Radical, a far-right political group that was banned after a member attempted to kill the president. The French radical right already had a rich history of political activism behind it before this protest. However, the Poitier demonstration featured several new twists. As Bruns, Glösel and Strobl point out, the four core elements of the international identitarian 'movement' were on display here: youth, actionism, popular culture and corporate identity. ${ }^{12}$

The 'movement' promotes itself as a generational response to the crises of European civilisation. This clarification has helped it distinguish itself from other existing far-right groups and create an image of youthful authenticity. The follow-up to the Poitier demonstration is a simple black-and-white YouTube video titled Declaration de Guerre (A Declaration of War) featuring angry young men and women speaking about their wasted lives and clearly blaming an unnamed "you".13

The actionist element lies in the way their angriness is expressed. The Poitier demonstration was an audacious, visually attractive protest that owed much to Greenpeace's style; it was presumably designed to get media attention - from classic mass media to social media. Its brief message was deeply symbolic, referring to the Reconquista and the Battle of Tours (also known as the Battle of Poitier), where Charles Martel defeated a Muslim army of the Umayyad Caliphate in 732 . The identitarians adopted a strategy involving visually striking, media-attractive forms of protest that are not based on the number of protesters but on performative creativity and cultural references and stereotypes.

These activists frequently incorporate visual and textual pop-culture references in their materials. The 'movement's' main symbol is the Greek letter lambda, a symbol the Spartan army painted on its shields. This image, however, does not come from historical sources, but from 300, a popular comic book adapted into a Hollywood movie in 2006. Some of the "movement's" videos, which are critical communication channels and mobilisation tools, borrow heavily from the film's visual aesthetics, particularly in their depiction of excitement, courage and peril. Identitarians use pop culture and history to make their agenda accessible and attractive.

The identitarian 'movement' has also built up a 'corporate identity' as a new element in the far-right scene. The first demonstration in Poitier featured the

\footnotetext{
11 For details, see Glösel, Strobl, Bruns (2014).

12 Glösel, Strobl, Bruns (2014), p. 56.

13 See Génération Identitaire (2013).
} 
basic components that identitarian groups from different countries still use today: the lambda symbol, the "generation identity" label, black-and-yellow graphics, and references to a modern-day 'Reconquista'. Although groups act independently on the national level, their visual style is maintained across national borders. The 'movement' thus copies the strategy of multinational corporations, which build global brands that are adopted nationally. The identitarian brand, however, emphasizes pan-European values and identity.

The 'movement's' common ideological and 'corporate' framework cannot make up for the national differences rooted in the far-right political scenes of each country. Fabian Virchow even doubts whether the identitarians can even be called a movement at all, as they possess only some of the key characteristics necessary for defining a group as a social movement. ${ }^{14}$ Therefore, he suggests identitarianism is a proto-movement with an open future. In recent years, the organisation of the 'movement' has stabilised: stable local groups are connected under the banner of a national group, which in some countries, such as Austria, has an overall leader. International cooperation, however, seems to be rare and occurs only on an ad hoc basis.

Now I shall examine the special features of identitarianism in different countries. I will start in France, the cradle of this 'movement'. The French organisation Génération Identitaire draws its ideology from the French New Right (see the next section), a connection French identitarians heavily market. It is also the national group that most resembles a youth political organisation. In fact, it was established as the youth wing of Bloc Identitaire at a time when this political group had ambitions of entering party politics. However, the success of Marine Le Pen's National Front that began in 2011 moved Bloc Identitaire away from party politics; it changed strategies and sought to become a political association with a broader impact on society. Through their Maison de l'Identité cultural and social centres and various media and publishing activities, ${ }^{15}$ they attempted to influence a wider audience in a 'grassroots' style. In 2016 the name of the organisation was changed from Bloc Identitaire to Les Identitaires, but the Génération Identitaire youth group remained a vital part. Apart from online activism, the youth organisation also held an annual summer school focused not only on political education, but also on practical political work (journalism, video recording and processing, banner making, etc.) and sport (boxing, self-defence). The French identitarian organisation

\footnotetext{
14 Virchow (2015), p. 186.

15 In March 2021 the youth organisation was dissolved by the French government on the grounds of inciting people to hatred and hostility. For the Les Idenititaires, see https:// www.les-identitaires.com/ [accessed 01.05.2019] and the websites of their regional groups.
} 
featured two attributes that distinguish it from other groups. Firstly, it prides itself in its role as the initiator of the international 'movement'. Secondly, it accentuates national symbols and stereotypes, highlighting historical figures such as Saint Genevieve, the patron saint of Paris, and making references to foods linked to national autostereotypes.

In Germany the Poitier protest and video found relatively wide popularity in 2012. Several identitarian groups were quickly founded. The first medialised protest was held in Frankfurt's municipal library during "Intercultural Week"; several activists in Guy Fawkes masks disrupted an event, blaring hardbass music, unfurling a banner with the identitarian logo and holding up a sign reading "bassing out multiculti" ("Multikulti wegbassen"). ${ }^{16}$ Since then identitarian groups have organised several protest performances that have received some media attention. Although these groups present themselves as a centrally organised movement with chapters in each Bundesland and national leaders, ${ }^{17}$ the overall organisational structure is fragmented and decentralised with some groups acting relatively independently, whereas others are inactive.

The Austrian identitarian movement has many links to the German one. The leading Austrian identitarian author, Markus Willinger, was born in Austria but studies in Stuttgart. He is author of the key German-language manifesto Die identitäre Generation: Eine Kriegserklärung an die 68er (Generation Identity: A Declaration of War Against the '68ers)..$^{18}$ Identitarians in both countries also draw from a shared far-right scene that produces journals such as Sezession, Neue Freiheit, and Blaue Narzisse. However, the Austrian identitarians, when compared to their German counterparts, are more active and better organised. The earliest groups were established in university cities with strong links to right-wing student clubs. ${ }^{19}$ Martin Sellner, a student at the University of Vienna and member of the far-right Burschenschaft Olympia student group, is the most visible national identitarian leader on a global scale. ${ }^{20} \mathrm{He}$ is the co-leader of the Austrian branch and has attracted the most media coverage by far. Austrian identitarians have succeeded not only in establishing a network of regional contact persons, but also in organising several regular events, including annual conferences, summer courses and numerous protest performances. So called "annual reports" and regular press reports contribute to building up their 'corporate identity'.

16 Glösel, Strobl, Bruns (2014).

17 See their website https://www.identitaere-bewegung.de/ [accessed 24.03.2021].

18 See Willinger (2014).

19 See Speit (2016).

$20 \quad$ See Weidinger (2016), p. 82 . 
Although a Swiss-German identitarian branch was launched in 2014, it is mostly inactive. Its activities are limited to copying German materials and presenting them on the internet and Facebook pages. Similarly, Swiss-French identitarians are heavily dependent on Génération Identitaire.

In Scandinavia, where there is an active and visible far-right scene that has been strongly influenced by French identitarian writers, identitarian groups lack the corporate style of continental European branches; their links to German and French identitarians are more virtual then real. As Benjamin Teitelbaum argues, the shift towards identitarianism is a part of a broader trend within the Nordic far-right scene, which has experienced the declining popularity of the skinhead subculture in favour of intellectualism and engagement in the culture wars. ${ }^{21} \mathrm{He}$ describes identitarianism as one of the three new nationalist streams in Scandinavia that has gradually evolved since 2004 under the influence of the French New Right ideology. After establishing an umbrella organisation, the National League, Scandinavian identitarians succeeded in developing three online platforms with international influence. From 2006 to 2015 the Motpol multiblog was highly popular among activists around Europe. ${ }^{22}$ Around the same time the Wikipedia-like platform Metapedia featuring identitarian content was established and soon translated into a number of languages. ${ }^{23}$ The third platform was the Nordisk.nu site featuring varied content, including discussion fora and music, with a peak of 20000 registered users. With the exception of Nordisk.nu, these platforms still exist today; in general the Scandinavian far-right scene still has a significant impact on other European groups mainly via Arktos Media, which publishes seminal works of the New Right and other ideologies, as well as fiction, history, and philosophy books in English. On the other hand, the complete absence of the Generation Identity corporate identity in Scandinavia is surprising at the very least and could be the result of older far-right activists dominating the scene.

In southern Europe, only Italy has an active identitarian scene. Since 2012 several Generazione Identitaria groups have been established; they draw heavily from their high-profile Rome-based neo-fascist CasaPound forerunners and also have French inspiration. They have adopted the identitarian corporate identity including the main themes of Reconquista, ethno-pluralism, and support for youth sport. Their protest style includes using stickers to express political messages in public spaces. For example, in 2018 they affixed stickers reading "islamizzazione" (Islamisation) to stop signs in the centres of many

\footnotetext{
$21 \quad$ See Teitelbaum (2017).

22 See https://motpol.nu/ [accessed 23.03.2021].

23 See https://en.metapedia.org [accessed 23.03.2021].
} 
Italian cities. ${ }^{24}$ This strategy resembles the culture jamming strategies of anti-consumerist movements inspired by the French Situationist International from 196os onwards.

In 2017 several groups emerged in other western and southern European countries, such as the Belgian Generatie Identiteit and the Danish Identitaer. In the United Kingdom and Ireland, the identitarian group was officially launched in 2017 and started to be active in 2018 and there is a sign of identitarian activities in Spain in Catalonia.

There is a clear distinction in the transfer of identitarianism to postsocialist countries. National branches in the Czech Republic and Slovenia have been in continuous existence since 2013, put on regular public performances, and possess their own, partly specific, styles. Both groups were established in regions bordering German-speaking countries and were inspired by their neighbours' activist scenes. The Hungarian group's beginnings date back to 2014, but it started to be more active in 2016. In 2017 when the identitarian "Defend Europe" campaign gained international attention, several other Eastern European branches attempted to organize independent actions. The Polish Pokolenie Tożsamości is not stable, but it took part in a Polish nationalist demonstration in 2017. A Serbian group also organised several protests and debates in 2017.

If we examine European identitarianism as a whole, several regional distinctions emerge. Firstly, identitarianism is clearly centred in France and Germany, countries that have inspired the Scandinavian and Eastern European far-right scenes. Additionally, in these two countries, where immigration is a hotly debated topic, far-right politics in general have seen a resurgence. In France there is a strong traditional right-wing party that supports smaller groups. In Germany the far right has only moved away from the edge of legality in recent years with the establishment of anti-immigrant political parties and movements (AfD, Pegida). Identitarian metapolitics offers a promising strategy in this country with strong anti-hate-speech legislation.

Secondly, postsocialist countries either have been influenced by the German-language activist scene (Czech Republic, Slovenia) or have their own far-right political groups that are part of the political mainstream (Poland, Hungary). The lack of a still active generation of '68ers' and weakened liberal political currents also weaken the image of the alleged enemy of the identitarian 'movement' there.

24 For their own presentation of this campaign, see https://generazione-identitaria.com [accessed 24.03.2021]. 
Thirdly, Scandinavia and southern European countries have strong domestic far-right scenes, and identitarian groups there do not follow the identitarian corporate style; thus, active groups in Spain and Sweden tend to follow more their own national traditions of far-right politics.

The ideological roots of the identitarians lie in GRECE, a New Right group founded in 1968, and the ideas of its founders, Alain Benoist and Guillaume Faye. Benoist summarised his longstanding criticism of liberal egalitarianism in an eclectic and sometimes contradictory essay titled On Identity that was first published in French in the GRECE journal Éléments. ${ }^{25}$ It was later translated into English, German, and Italian and reworked into the book Nous et les Autres. Problématique de l'identité. ${ }^{26}$

He starts by establishing identity as a distinct modern concept present in the academic discourses of psychology, sociology, and social anthropology. Drawing from Charles Taylor's communitarian approach to identity, among other things, he sketches a narrative of the modernist notion of identity beginning with the eighteenth-century philosophy of individualism, Descartes's rationalism, and Locke's philosophy of free will. With the presumed crisis of Western nation-states, which had long been modern man's main source of selfrecognition, the need for an alternative base for identity-building had come. He refers to contemporary minority identity politics (giving examples of gay, African-American, and ethnic movements) without contextualising them in the identity politics of NSMS, and ascribes them a non-universalist position as opposed to the modernist liberal notion of group interests. In this way he presents them as victims of the modern universalist claim that identity is a private matter. This interpretation allows him to claim that inherited differences must be accepted and considered part of one's identity: belonging to a group "will only determine [one's identity] if belonging to a nation or to any other entity is the decisive criterion for one's thoughts and actions". ${ }^{27}$ Here Benoist openly shifts the function of identity. It is no longer a problem of modern society that should be studied or something that minority groups struggling for recognition should grasp; it is one's cultural heritage that needs to be 'accepted' in the face of modern liberal universalism.

\footnotetext{
25 See Benoist (2004a).

26 See Benoist (2006).

27 Benoist (2004b), p. 42.
} 
It should be noted that Benoist also criticizes essentialism, which overestimates the stability of identity and overlooks its constantly changing nature. In a section on the pathology of identity he mentions that even if the presence of an enemy gives a group a social identity, it is only a negative identity and not an expression of identity in its own right. He also calls for identities to be constructed in a dialogic process, based on one's relationship with the other; thus identities should not mutually exclude each other. Behind this call for dialogue, however, lies the ethno-pluralist approach of the New Right, which states that the unique traditions and cultures of nations and ethnic groups have to be kept separate in order to preserve them. ${ }^{28}$ Benoist's concept, which was highly popular among nationalists around Europe, is formulated as a positive notion of difference and inconspicuously but tellingly leaves aside the need to separate different identity groups implicit in it.

If Benoist's argumentation clearly demonstrates continuity with NSM identity politics, the strategy identitarians have built on these ideological grounds transforms this continuity into the performative context of specific cultural and historical stereotypes. An illustrative example is the "Defend Europe" motto around which various campaigns were organised. In 2017 a nine-minute video was made using materials from different national identarian groups with the goal of unifying European identitarianism. ${ }^{29}$ It begins with marching young people prominently displaying the identitarian symbol before a title card reading "Defend Europe" appears; it then focuses on different countries, showing national symbols and each branch's activities. The German part starts with shots of the Niederwald Monument and the Hermann Monument, which commemorate the nineteenth-century unification of Germany and the pre-Christian Germanic victory over Romans, respectively. This is followed by an intertitle reading "European people are dying because we are tolerant to those who don't respect our identity." The rest of the clip portrays various manifestations and public performances arranged by country. The final shot is of the Acropolis in Athens with the identitarian lambda flag in the foreground. A title card reading "United for our children" then appears.

The video presents a disparate mix of images--shots from tourism videos depicting nationalist memorials and amateur footage from youth demonstrations. It combines alarmist rhetoric with symbols of national glory and the determination to defend them. Hence, it refers to both national and European popular memory, the source of the identity endangered by a vaguely presented

28 See Rydgren (2007), p. 244.

29 See Spotlight70o (2017). 
enemy. While Benoist writes about 'accepting' and 'considering' one's own identity, this presentation conjures up ideas of active "defence" against an external enemy.

This "defence" rhetoric has been put into action during numerous protests and performances around Europe, such as the Paris Pride March (Marche de la journée de la fierté Parisienne). Since the early 200os, a group called Paris Pride (Fierté Paris) has organised, alongside identitarian groups from Paris, evening-time torch-lit marches around the feast day of Saint Genevieve (January 3) under the slogans "Defend Paris" or "Defence of Paris" ("Défendons Paris" or "Défence de Paris"). ${ }^{30}$ The defence rhetoric is also present in speeches made during this event, where speakers compare Saint Genevieve's defence of Paris against Attila the Hun to the present goal of defending it against Islamists.

Other minor performances using similar rhetoric have also been organised, usually in the form of banner drops in public spaces. One example would be a demonstration held by Czech identitarians -- the unfurling of a banner reading "Our people first" ("Naši lidé na prvním miste"”) at the National Gallery in Prague in front of Ai Weiwei's Law of the Journey, an installation consisting of a large inflatable boat and inflatable figures wearing life vests. A photo was published on the Czech identitarians' webpage with the caption "Our politics is not based on hate towards others but love for our own kind" ("Naše politika nevychází z nenávisti k ostatním, ale z lásky ke svým"). ${ }^{31}$ This statement demonstrates the paradox of the identitarian position: they claim they care just about "our" identity, but through performance they communicate symbolic messages of war against an internal and external enemy.

The identitarian campaign that has received the most international attention was the Defend Europe "mission"; its aim was to block search-and-rescue ships operated by NGOs in the Mediterranean. This "mission" was launched in spring 2017 with a fundraising campaign targeting American and European far-right supporters. Identitarian activists hired the C-Star, which departed from Djibouti; however, there were severe complications with finding a place to dock on European shores. For example, Northern Cyprus detained the ship's crew over accusations of people smuggling. The activists finally began their

30 It has been reported on mostly by far-right media in recent years as for example TV Libertés, Paris Vox, Novopress and French branches of Russian international media as Sputnik France and Russia Today France. See also the organizers' clips on YouTube, e. g. https://www.youtube.com/watch?v=amk5 Y7bRS6E [accessed 24.03.2021].

See Generace Identity (2017). 
mission in late July 2017. ${ }^{32}$ When the ship needed to be refuelled, it was blocked repeatedly by NGOS, local citizens, and the Tunisian and Maltese authorities; it ended up finishing its "mission" after one week of patrolling the seas. While having no impact on the activities of NGOs, the activists claimed that they were "monitoring" the situation and "trolling" NGOs using megaphones and banners reading "No way, you will not make Europe home" and "Stop human trafficking". ${ }^{33}$ Nevertheless, they proclaimed the "mission" to be an "undisputable and total success". ${ }^{34}$

Although this campaign lacked the references to cultural or historical identity of earlier demonstrations, it exemplifies the strategy identitarians use to transform the performance style of the old identity politics to meet their purposes. Since the early 1970s, Greenpeace has been conducting maritime blockades, most famously by the Rainbow Warrior. Hiring out a ship, however, did not help the identitarians make any practical changes, but it did gain them international publicity. Taking their cue from the protest culture of the established environmental movement, they have adapted it to their political agenda, in the process gaining attention in the media as the battleground of the cultural wars.

The ideological background of this strategy lies in the concept of metapolitics that was developed within the French New Right and is based on the Gramscian notion of cultural hegemony. As Benjamin Teitelbaum notes, when New Right authors studied their political opponents it brought them to the strategy of "pulling themselves and likeminded activists out from the margins of public life and injecting their message into the mainstream". ${ }^{35}$ These theorists, referencing Gramsci, claim that political change must begin with cultural struggle. In a 2011 manifesto Guillaume Faye writes that "social diffusion of ideas and cultural values for the sake of provoking profound, long-term, political transformation" is needed. ${ }^{36}$ While ideologues were debating these ideas in relative isolation in France in the 1970s and 1980s, during the 1990s the concepts of ethnopluralism and metapolitics spread widely among nationalists throughout Europe. In the 2ooos they were introduced to the identitarian 'movement', including its youth organisations.

\footnotetext{
32 This campaign was widely covered by international and national media in Europe. For a summary produced by the antiracist and antixenophobic think-tank Hope Not Hate, see Mulhall (2017).

33 Oppenheim (2017).

34 Defend Europe (2017).

35 Teitelbaum (2017), p. 42.

$36 \quad$ Faye (2011), p. 272.
} 
Although preserving culture is a crucial goal for identitarians, there is surprisingly little discussion about the definition of culture in identitarian ideological texts. Based on observations of identitarian performances, 'culture' could cover everyday culture, pop culture, traditional folk culture, collective memory, art, and even the humanities or scholarship in general. I will now present different examples of how European identitarian groups, in their protests and performances, have addressed culture in its various forms.

Identitarians perceive the internet and public space as crucial arenas of metapolitics. They use references to everyday mainstream culture to present their agenda through cultural auto- and heterostereotypes. In the 2ooos the French Bloc Identitaire used stereotypes about French food to play the anti-immigrant card. Their most medialised performance protest was the distribution of soup de cochon or soup identitaire ("pork soup" or "identity soup") to homeless people in areas in French cities with Muslim and Jewish populations in the 20oos. These activities peaked with a highly controversial performance that was planned for Paris in 2010 and titled "pork sausage and booze party" ("apéro saucisson et pinard"), which was banned by local police after protests by various local communities. ${ }^{37}$

The erection of a memorial to "the victims of multiculturalism and Islamic terror" (as it was presented in the right-wing media) in Berlin in 2017 was a public performance that referred to cultural memory in multiple ways. ${ }^{38}$ This performance was part of the German identitarians' new strategy of establishing single-purpose campaigns linked to topical issues discussed in the public arena..$^{39}$ On the first anniversary of the massacre on Berlin's Breitscheidplatz, where a truck was driven into the Christmas market in December 2016, city authorities dedicated a monument to this event at the site of the attack. While a ceremonial unveiling was taking place on Breitscheidplatz, several identitarians constructed a concrete monument in front of the Brandenburg Gate. Activists set five concrete blocks there inscribed with the slogans "To the victims of Islamist terror" ("Den Opfern Islamistischen Terrors") and "No victim is forgotten" ("Kein Opfer ist vergessen") and the names of European cities where terrorist attacks had been committed in recent years. After several hours the blocks were removed by the police as they were placed there illegally. ${ }^{40}$ This

\footnotetext{
37 Mestre and Monnot (2010).

$38 \quad$ Berger (2017).

39 They establish specific websites with short statements and clips without open references to the identitarian 'movement'. See e. g. https://www.identitaere-bewegung.de/projekte/ kein-opfer-ist-vergessen/ [accessed 24.03.2021]. 
performance act made at least three cultural references. Firstly, the image of concrete blocks resembles the Holocaust memorial that was erected nearby in 2005. Hence, identitarians linked Islamists with the denounced Nazi regime to legitimize their protest. Secondly, candles, photos, and flowers were laid out, making the monument resemble an authentic mourning site. The audience of this act was supposed to perceive the place as an authentic place of memory. Thirdly, it reflected the media debate about the inscription on the official monument at Breitscheidplatz, where the word Islamist was not included in the official inscription. By including this word in their inscription the identitarians targeted the alleged hypocrisy of the authorities. Even though this performance touched upon many controversial issues, it gained only minor publicity in the local media.

Identitarians also react to current political issues popular in the media to support their own agenda. For instance, in 2018 a group of German identitarians started a media campaign in reaction to the \#MeToo campaign against sexual assault and harassment. It was called the 120 Decibel movement with the subtitle "the real outcry", a reference to the volume of pocket alarms used by women in danger, and calls upon women to speak about their experience with "imported violence". ${ }^{41}$ In addition to producing a mobilisation video, campaign organizers have also disrupted a panel discussion about the \#MeToo campaign at the Berlinale film festival and put on a street theatre performance titled "Dead Girls Don't Lie" ("Tote Mädchen lügen nicht") in front of the parliament in Schleswig-Holstein. This campaign links depictions of fear and vulnerability with the need for speaking out on violence against women, an idea borrowed from the \#MeToo campaign to legitimize the exaggeration of immigrant violence and arouse xenophobia.

The Czech identitarian 'movement' has most prominently protested by recontextualising meaning in contemporary art. Apart from the protest in the National Gallery mentioned above, the Czech identitarian group also stepped into the public realm by conducting an "aesthetic intervention" in Prague in November 2016. The subject of their protest was controversial Czech artist David Černý's sculpture in the courtyard of the Kafka Museum. Activists covered Černýs fountain - featuring the statues of two men urinating on a map of the Czech Republic - with a tarp, wrapped it up in black-and-yellow tape, and spread political leaflets around it. A report on the group's website refers to the fountain as "quasi-art that is vulgar and offends the Czech nation". ${ }^{42}$ Even

41 The campaign's website has been deleted since then.

42 Generace Identity (2016). 
though Černý is well known for his provocative artworks in public spaces that question Czech autostereotypes, this performance had little public impact.

The identitarians have also co-opted traditional folk culture events, most notably in Germany. In 2016 and 2017 identitarians from Harz snuck into the carnival parade in the town of Derenburg masked as Spartan warriors, holding shields marked with the lambda sign and pushing a figure dressed as Angela Merkel, who was dishonouring the German flag. ${ }^{43}$ Even though the president of the carnival association was outraged, the organizers did nothing to stop them. The president argued that the carnival is not meant to promote any political group or party; its main aim is "fun". ${ }^{4}$ The identitarians countered on their Facebook page by claiming that political statements are present at various German carnivals. A similar performance was organised by the identitarian group from Schwaben in January 2018, when activists disrupted a parade, masked in burkas and carrying a banner reading "Women rights movement Burkaria 2022, equal in rights, self-determining, free" ("Frauenrechtsbewegung Burkaria 2022, gleichberechtigt, selbstbestimmend, frei"). Local police investigated this act because some of the carnival participants complained about the content of the leaflet that identitarians had distributed. The group proclaimed their demonstration to be a great success and added that "carnival, as a hundred-year-old custom, is perfectly suitable for holding up a mirror to society and its elites".45 Through "mirroring" mainstream cultural practices identitarian ideology is put into action and presented to a local public.

\section{Conclusions: The Europeanisation of Far-Right Youth Culture?}

Identity as a category of practice has undergone a strange shift in recent decades. Rooted in the academic discourse of the 1950s and 1960s, it became a key concept in the anti-establishment radical movements of the 1970s and 198 os, which opposed the mainstream discourse by raising the self-consciousness of marginalised groups. New Right ideologues observed the success of these NSMs in the 199os and gradually adopted an ideological framework with which they could fight against NSMs' agendas on the same field. In the 2000 s these thinkers offered a solid ideological foundation for a new generation of far-right activists fighting against the liberal and universalist mainstream. From their political opponents the far right adopted culture as the main

\footnotetext{
43 Freie-Heimat (2017).

44 Volkstimme.de (2017).

45 Widemann (2018).
} 
political battleground, and it adapted the left's forms of protest that attract public attention. Use of the internet and social media and cultural performances have been established as the key instruments for promoting political agendas. As NSM strategies were accepted by the mainstream, they eventually made their way to the far right, where the original focus on universal rights and identity politics came under attack by the identitarian 'movement', which claims to defend the cultural identity of the majority.

The new far right in the West has marked '68ers' as the main enemy for having disrupted the traditional value system. Although identitarians present themselves as a pan-European movement, this 'enemy' is not equally strong in all European countries. Identitarianism has been most successful in France and German-speaking countries, whereas in Scandinavia, southern Europe it has not caught on so well. In the United Kingdom the identitarian groups have mobilised new activists and gained public presence as late as 2018. Interesting borderline cases are the Czech Republic and Slovenia. This European divide was further exacerbated by mass immigration to France and Germany during the 2015 crisis. In southern Europe only Italian identitarians have successfully organised their own demonstrations. Consequently, it supports the thesis that the new far-right, which sees its enemy in migrants and '68ers', has been the most successful in European core countries. Follow-up research, however, is still necessary.

As identitarians oppose the modern liberal paradigm of history because it contradicts memory (as formulated by Pierre Nora), the frame of reference in national, European, and regional memory and mythology plays a very important role. Identitarians have fought on the "battleground of culture" by carefully mobilising historical and cultural stereotypes as part of cultural performances that are attractive to the mainstream media. Modern notions of history as the scientifically reconstructed knowledge of the past have taken a back seat to a highly selective process of forming a collective memory.

Thus, the far-right identitarian 'movement' just mirrors the strategies initially developed by new social movements in their pursuit of identity politics and universal rights, which gives this proto-movement rather limited perspectives for the future. Even though identitarians have successfully addressed a specific section of the youth in some European countries, their role in shifting the general public discourse towards a xenophobic and nationalist agenda has been rather insignificant in comparison to that of established far-right political parties, which have grown in popularity in Europe since the immigration and economic crises.

Furthermore in 2018 and 2019 state authorities in France, Austria and Germany started to check the legality of identitarians' organisations and activities. Their vigilant and guarded strategy helped them to defend their position, for 
example in a legal dispute in Graz, Austria, where they were accused of criminal association and hate speech but found not guilty. Throughout the year 2018 the Facebook and Instagram pages of identitarian groups in various countries were banned, which was followed by establishing new ones which were again banned. With this new repressive wave, the identitarian 'movement' seems to be neither weakened nor reinforced and remains a marginal but stable part of the far-right political scenes throughout Europe. ${ }^{46}$

\section{Bibliography}

Benoist, Alain (2004a). 'Qu'est-ce que l'identité ?'. https://s3-eu-west-1.amazonaws. com/alaindebenoist/pdf/qu_est_ce_que_l_identite.pdf [accessed o1.05.2019].

Benoist, Alain (2004b). 'On Identity', Telos, 128, pp. 9-64.

Benoist, Alain (2006). Nous et les Autres. Problématique de l'identité (Paris: Crisis).

Berger, David (2017). 'Brandenburger Tor. Erstes europäisches Denkmal für die Opfer von Multikulti und islamistischen Terrorismus'. https://philosophia-perennis. com/2017/12/19/ib-brandenburger-tor/ [accessed 24.03.2021].

Bornschier, Simon (2018). 'Globalization, Cleavages, and the Radical Right', in Jens Rydgren (ed.), The Oxford Handbook of the Radical Right (Oxford: Oxford University Press). https://www.oxfordhandbooks.com/view/10.1093/oxfordhb/9780190274559 .001.0001/oxfordhb-9780190274559-e-11 [accessed 24.03.2021].

Brubaker, Rogers, Frederick Cooper (2000). 'Beyond “Identity", Theory and Society, 29.1, pp. 1-47.

Calhoun, Craig (1994). 'Social Theory and the Politics of Identity', in Craig Calhoun (ed.), Social Theory and the Politics of Identity (Oxford: Blackwell), pp. 9-36.

Defend Europe (2017). The Successes of Defend Europe (online video recording), YouTube, 23 August. https://www.youtube.com/watch?v=NpsDDtOC-yc [accessed 23.03.2021].

Faye, Guillaume (2011). Why We Fight. Manifesto of the European Resistance (London: Arktos).

Freie-Heimat (2017). Identitäre Bewegung Harz - Beitrag zum Aschermittwoch (online video recording).YouTube,1March.https://www.youtube.com/watch?v=BteFK44Li3g [accessed 01.05.2019].

Generace Identity (2016). 'Estetická intervence v Praze'. http://generace-identity.cz/ tag/david-cerny/ [accessed 23.03.2021].

46 This work was supported by the European Regional Development Fund project "Creativity and Adaptability as Conditions of the Success of Europe in an Interrelated World" (reg. no.: CZ.o2.1.01/o.o/o.o/16_o19/oooo734). 
Generace Identity (2017). 'Estetická intervence „Naši lidé na prvním místě“ v Národní Galerii'. http://generace-identity.cz/esteticka-intervence-nasi-lide-na-prvnimmiste-v-narodni-galerii/ [accessed 01.05.2019018].

Génération Identitaire (2013). Déclaration de guerre - Génération Identitaire (version sans musique) (online video recording), YouTube, 20 January. https://www.youtube. com/watch?v=5Vnss7ygTNA [accessed 23.03.2021].

Gleason, Philip (1983). 'Identifying Identity. A Semantic History', The Journal of American History, 69.4, pp. 910-932.

Glösel, Kathrin, Natascha Strobl, Julian Bruns (2014). Die Identitären. Handbuch zur Jugendbewegung der Neuen Rechten in Europa (Münster: Unrast Verlag).

Hobsbawm, Eric (1996). 'Identity Politics and the Left', New Left Review, 217, pp. 38-47.

Hunt, Scott, Robert D. Benford, David A. Snow (1994). 'Identity Fields. Framing Processes and the Social Construction of Movement Identities', in Enrique Larana, Hank Johnston, Joseph R. Gusfield (eds), New Social Movements (Philadelphia: Temple University Press), pp. 185-209.

'Identitäre Bewegung stellt Grabsteine vor Brandenburger Tor' (2017). Die Welt, 19.12.2017. https://www.welt.de/politik/deutschland/article171744110/IdentitaereBewegung-stellt-Grabsteine-vor-Brandenburger-Tor.html [accessed 23.03.2021].

Klein, Adam (2017). Fanaticism, Racism, and Rage Online. Corrupting the Digital Sphere (London: Palgrave Macmillan).

Lilla, Mark (2017). Once And Future Liberal. After Identity Politics (Toronto: HarperCollins).

Mestre, Abel, Caroline Monnot (2010). 'Extrême droite. L'apéro "saucisson et pinard" de la Goutte-d'Or interdit', 16 June. https://www.lemonde.fr/societe/article/2010/o6/16/ extreme-droite-l-apero-saucisson-et-pinard-de-la-goutte-d-or-interdit_1373693_3224. html [accessed 23.03.2021].

Mulhall, Joe (2017). 'Failed Defend Europe Mission Comes to an End'. https://www.hopenothate.org.uk/2017/o8/17/failed-defend-europe-missioncomes-end/ [accessed 23.03.2021].

'Rechte “Identitäre Bewegung” besetzt Brandenburger Tor' (2016). Die Welt, 27 August. https://www.welt.de/newsticker/dpa_nt/infoline_nt/brennpunkte_nt/article157879235/ Rechte-Identitaere-Bewegung-besetzt-Brandenburger-Tor.html [accessed 24.03.2021].

Oppenheim, Maya (2017). 'Defend Europe. Far-RightShip Stopping Refugees Ends Its Mission after a Series of Setbacks', The Independent, 21 August.https://www.independent.co.uk/ news/world/europe/defend-europe-far-right-ship-stop-refugees-mediterranean-endmission-c-star-setbacks-migrant-boats-a7904466.html [accessed 24.03.2021].

Rorty, Richard (1998). Achieving Our Country. Leftist Thought in Twentieth-Century America (Cambridge, Mass: Harvard University Press).

Rydgren, Jens (2007). 'The Sociology of the Radical Right', Annual Review of Sociology, 33, pp. 241-62 
Speit, Andreas (2016). Bürgerliche Scharfmacher. Deutschlands neue rechte Mitte - von AfD bis Pegida (Zürich: Orell Füssli).

Spotlight70o (2017). Europeans Unite to Defend Europe (online video recording), YouTube, 18 March. https://www.youtube.com/watch?v=Tsjh 5 FoNxNo\&t=296s [accessed 01.05.2019].

Teitelbaum, Benjamin R. (2017). Lions of the North. Sounds of the New Nordic Radical Nationalism (New York: Oxford University Press).

Virchow, Fabian (2015). "The "Identitarian Movement". What Kind of Identity? Is it Really a Movement?', in Patricia Anne Simpson, Helga Druxes (eds), Digital Media Strategies of the Far Right in Europe and the United States (Lanham, Maryland: Lexington Books), pp. 177-19o.

Volkstimme.de (2017). "Derenburg geht auf Distanz". https://www.volksstimme.de/ lokal/wernigerode/karneval-missbraucht-derenburg-geht-auf-distanz [accessed 24.03.2021].

Weidinger, Bernhard (2016). 'Völkische Studentenverbindungen und Rechtsextremismus in Österreich', in Albert Steinhauser, Harald Walser (eds), Rechtsextremismus-Bericht 2016 (= Bericht zu den Ergebnissen der „Rechtsextremismus-Enquete“ der Grünen von 2015) (Vienna: Die Grünen - Der Grüne Klub im Parlament), pp. 77-87. Widemann, Wolfgang (2018). "Rechte Gruppierung mischt sich unter Narren im Faschingsumzug", Augsburger Allgemeine, 30 January. https://www.augsburgerallgemeine.de/donauwoerth/Rechte-Gruppierung-mischt-sich-unter-Narren-imFaschingsumzug-id44029536.html [accessed 24.03.2021].

Willinger, Marcus (2014). Die identitäre Generation (London: Arktos). 